\title{
Simulation of three-dimensional chemical dissolution of limestone
}

\section{Kireçtaşının üç boyutlu kimyasal çözünme simülasyonu}

\author{
Hitoshi MATSUBARA ${ }^{*}$ iD , Takashi ITO2* iD \\ 1,2School of Civil Engineering, University of the Ryukyus, Okinawa, Japan. \\ matsbara@tec.u-ryukyu.ac.jp, takito@tec.u-ryukyu.ac.jp
}

\section{Abstract}

The development of prediction techniques for the evolution of karstic caves is essential for geohazard prevention because limestone collapse commonly accompanies their complex dissolution process. Previous studies to understand the dissolution mechanisms focus on field-based and/or small-scale experimental approaches. Although several largescale numerical simulations have been conducted due to improved computing capabilities, mathematical modelling and numerical simulation for the three-dimensional dissolution of limestone remains unavailable. In this study, we examine the three-dimensional dissolution phenomenon of calcium carbonate in limestone and propose mathematical and numerical models based on an advection, reaction, and diffusion system involving Darcy's law. Additionally, we implement the models using a finite difference method involving the constrained interpolation profile with conservative semi-Lagrangian scheme, and dissolution patterns of the calcium carbonates obtained by the proposed model are presented. The simulation demonstrates that the dissolution of calcium carbonate is strongly related to the groundwater flow, with increasing pores and cavities toward the groundwater flow direction, and the dissolution rate depends on the contact area between the groundwater and limestone.

Keywords: Limestone dissolution, Advection-reaction-diffusion system, Finite difference method, CIP_CSL2 scheme.

\section{Introduction}

Rock weathering is associated with geohazards such as landslides, rock falls, and sinkhole. Therefore, understanding the mechanisms involved is essential for sustaining the society and life. Although weathering has been extensively studied, integrated studies elucidating the phenomena are rudimentary. This is because of its complexity, as it involves mechanical, chemical, and biological components that are often studied separately in different fields including engineering.

The sinkhole mainly occurs in karst environments through the dissolution of the calcium carbonates in limestones by flowing groundwater and rainfall [1],[2]. The sinkhole sometimes causes by damaging underground structures such as the bursting of water pipes which are gradually eroded over time. Thus, this phenomenon significantly impacts human life, and therefore, urgent attention is needed to prevent such hazards in modern society.

Additionally, karstic caves are formed by chemical dissolution through reactions lasting decades or hundreds of years [1]. Chemical weathering of rocks has been observed worldwide, with many studies examining the relationship between the weathering and rock collapse [3]-[5]. However, the

\section{Öz}

Yeraltı bosluklarının kimyasal reaksiyon evrimine bağlı tahmin tekniklerinin geliştirilmesi çökme tehlikeleri açısından önemli olup kireçtaslarında görülen çökme karmașı çözünme ișlevleri ile gerçekleşmektedir. Bu bağlamda, çoğu arastırmacl çözünme mekanizmasını arazi ve/veya küçük ölçekli laboratuvar deney yaklașımları ile anlamaya çalıșmaktadır. Bilgisayar performanslarının gelișmesiyle fazla sayıda büyük ölçekli sayısal simülasyon çalısmalarının yapılmasına rağmen, günümüze değin kireçtasında üç boyutlu matematiksel modelleme ve sayisal simülasyon gerçekleștirilmemiștir. Bu çalısmada, yazar kireçtasındaki kalsiyum karbonatın çözünme olayına odaklanmış ve adveksiyon-reaksiyondifüzyon ve Darcy kanununu temel alan matematiksel bir model sunmuştur. Ayrıca, yazar modeli, sonlu farklar yöntemi CIP_CSL2 düzenine uygulamıștır. Bu çalıșmada, önerilen model ile belirlenen kalsiyum karbonatın bazı çözünme paternleri sunulmuștur. Sonuç olarak, kalsiyum karbonatın yeraltı suyu akışı ile doğrudan ilișkili olarak çözündüğü ve gözenekler ile mağaraların yeraltı suyu akıșı yönünde genişlediği ve çözünme miktarının yeraltı suyu ile kireçtaşı arasındaki temas alanına bağlı olduğu sayısal olarak gösterilmiștir.

Anahtar kelimeler: Kireçtası çözünmesi, Adveksiyon-reaksiyondifüzyon sistemi, Sonlu farklar metodu, CIP_CSL2 metodu.

development and investigation of temporal prediction and field monitoring techniques for limestone dissolution requires attention.

Several approaches for predicting rock dynamics and in situ monitoring systems have been proposed [6]-[9]. For example, a fracture propagation simulation technique based on the finite element method with voxel elements is available [6]. In this approach, a simple algorithm in which voxel elements are determined as fractured elements in an element-wise manner is employed to achieve robust numerical simulations. This approach enabled the assessment of failure patterns even under pure compression.

Furthermore, Kumsar et al. [9] proposed a novel technique combining a field monitoring system and the conventional limit equilibrium method and applied this to a creep-like landslide in Babadağ, Turkey. The unique mechanism of the landside was revealed by numerical simulation and in situ field investigation. In the laboratory, the dissolution and precipitation of calcium carbonate in limestone are easily measured. For example, a simple model was introduced for understanding the dissolution and precipitation processes of calcium carbonate and gypsum [10]. Using this model, their concentrations in dissolution reactions can be calculated in the laboratory.

\footnotetext{
${ }^{*}$ Corresponding author/Yazışılan Yazar
} 
Recently, Matsubara and Yamada [11] presented a mathematical and numerical approach based on the advection, reaction, and diffusion systems, allowing calculations for the calcium carbonate dissolution process. Through this approach, complex calcium carbonate dissolution patterns such as the dissolution of limestones with openings are achievable. Other studies for evaluating calcium carbonate dissolution also exist [12]. Moreover, the time-dependent mechanical stability of caves was studied by empirical, analytical, and numerical methods [13],[14]. However, the three-dimensional (3D) dissolution patterns of calcium carbonate in limestone has received little attention, with existing studies mostly involving one or two-dimensional (1D or 2D) simulations. Therefore, developing accurate 3D calcium carbonate dissolution simulation techniques is important for understanding the morphology, response to weathering and stability of karstic caves.

Therefore, in this study, we investigate the temporal and spatial morphological patterns of calcium carbonate dissolution and present 3D mathematical and numerical models based on the approach by Matsubara and Yamada [11]. That is, a 3D technique based on the advection, reaction, and diffusion systems is proposed. Several 3D calcium carbonate dissolution patterns are presented and the formation of these patterns for karstic caves discussed. The results of this study help in mitigating geohazards associated with limestone by chemical weathering.

\section{Mathematical and numerical formulations}

\subsection{Mathematical formulation and discretisation}

Calcite (calcium carbonate), the primary mineral in limestone is dissolved by acidic solutions [2]. Its dissolution and precipitation reaction (reversible reaction) is typified by the following:

$$
\mathrm{CaCO}_{3}+\mathrm{H}_{2} \mathrm{CO}_{3} \underset{k_{2}}{\stackrel{k_{1}}{\rightleftarrows}} \mathrm{Ca}^{2+}+2 \mathrm{HCO}_{3}^{-}
$$

where $k_{1}$ and $k_{2}$ are the reaction rates for the forward and reverse reactions, respectively. The Reaction in Equation (1) was also employed for a 2D model by Matsubara and Yamada [11]. Following the study, this equation was adopted as the basic chemical reaction to formulate subsequent mathematical expressions in this study [15].

Considering the spatial patterns of chemical reaction systems, extremely complex but organised patterns can be obtained using a reaction-diffusion system [16]. Therefore, herein, the reaction in (1) is mathematically formulated using the reaction-diffusion system to demonstrate the complex dissolution patterns of karstic caves. Moreover, advection terms are introduced for the ionic and liquid parameters in this system to account for groundwater flow according to using the following equations [11]:

$$
\begin{gathered}
\frac{\partial \boldsymbol{A}}{\partial t}=-k_{1} \boldsymbol{A B}+k_{2} \boldsymbol{C} \boldsymbol{E}^{2} \\
\frac{\partial \boldsymbol{B}}{\partial t}=-k_{1} \boldsymbol{A B}+k_{2} \boldsymbol{C} \boldsymbol{E}^{2}+\nabla\left(D_{\boldsymbol{B}} \nabla \boldsymbol{B}\right)-\nabla(v \boldsymbol{B})
\end{gathered}
$$

$$
\begin{gathered}
\frac{\partial \boldsymbol{C}}{\partial t}=k_{1} \boldsymbol{A} \boldsymbol{B}-k_{2} \boldsymbol{C} \boldsymbol{E}^{2}+\nabla\left(D_{\boldsymbol{C}} \nabla \boldsymbol{C}\right)-\nabla(v \boldsymbol{C}) \\
\frac{\partial \boldsymbol{E}}{\partial t}=2 k_{1} \boldsymbol{A B}-2 k_{2} \boldsymbol{C} \boldsymbol{E}^{2}+\nabla\left(D_{\boldsymbol{E}} \nabla \boldsymbol{E}\right)-\nabla(v \boldsymbol{E})
\end{gathered}
$$

where the concentrations of $\mathrm{CaCO}_{3}, \mathrm{H}_{2} \mathrm{CO}_{3}, \mathrm{Ca}^{2+}$, and $\mathrm{HCO}_{3}^{-}$are denoted as $\boldsymbol{A}, \boldsymbol{B}, \boldsymbol{C}$, and $\boldsymbol{E}$, respectively. These variables depend on the temporal and spatial functions. The terms $D_{\boldsymbol{B}}, D \boldsymbol{c}$, and $D_{\boldsymbol{E}}$ are the diffusion coefficients of $\mathrm{H}_{2} \mathrm{CO}_{3}, \mathrm{Ca}^{2+}$, and $\mathrm{HCO}_{3}^{-}$, respectively, and involve random spatial values. The term $v$ is the Darcy velocity calculated from the Darcy equation [17], and the values for arbitrary points are calculated through Equations (6) and (7) given as:

$$
\begin{gathered}
\nabla(-k \nabla h)=0 \\
v=-k \nabla h
\end{gathered}
$$

where $h$ and $k$ are the total potential head and hydraulic conductivity, respectively.

The hydraulic conductivity $(k)$ is negatively correlated to the concentration of $\mathrm{CaCO}_{3}(\mathrm{~A})$. That is, when the concentration of $\mathrm{CaCO}_{3}$ is high, the hydraulic conductivity is low, and vice versa. In this study, the linear relationship assumed between $k / k_{\min } / k_{\max }$ and $\boldsymbol{A} / \boldsymbol{A}_{\min } / \boldsymbol{A}_{\max }\left(k_{\min }\right.$ and $k_{\max }$ : minimum and maximum value of $k$, respectively; $\boldsymbol{A}_{\min }, \boldsymbol{A}_{\max }$ : minimum and maximum value of $\boldsymbol{A}$, respectively) is given as follows:

$$
k=\left(k_{\min }-k_{\max }\right) \frac{\boldsymbol{A}}{\boldsymbol{A}_{\max }}+k_{\max }
$$

This implies that the flow paths depend on the hydraulic conductivities at grid points with changes based on the limestone dissolution state (Equation (8)). Additionally, the diffusion coefficients are associated with the $\mathrm{CaCO}_{3}$ concentrations as follows:

$$
D_{\boldsymbol{B} / \boldsymbol{C} / \boldsymbol{E}}=\left(D_{\boldsymbol{B} / \boldsymbol{C} / \boldsymbol{E} \min }-D_{\boldsymbol{B} / \boldsymbol{C} / \boldsymbol{E} \max }\right) \frac{\boldsymbol{A}}{\boldsymbol{A}_{\max }}+D_{\boldsymbol{B} / \boldsymbol{C} / \boldsymbol{E} \max }
$$

where the minimum and maximum values of $D_{B / C / E}$ are denoted as $D_{B / C / E \min }$ and $D_{B / C / E \max }$, respectively.

The material characteristics of the limestone change with increasing calcium carbonate dissolution according to Equations (8) and (9). As the water flow channels of a limestone aquifer can be complicated, errors can easily arise in their modelling. Therefore, the discretisation scheme for the advection terms in Equations (2)-(5) must be highly accurate. In this study, the constrained interpolation profile with conservative semi-Lagrangian (CIP-CSL2) method [18],[19] was implemented for the advection terms. The CIP-CSL2 method was developed as an exact conservative scheme for advection at different concentrations [19]. Therefore, it is an optimal scheme for this study dealing with varying advection as expressed in Equations (3)-(5).

Equations (2)-(5) can be rewritten as follows:

$$
\frac{\partial G}{\partial t}=D+R-\nabla(v G)
$$

where $G, D$, and $R$ are the arbitrary variable, diffusion term, and reaction term, respectively. The advective transport is then expressed as Equation (11). 


$$
\frac{\partial G}{\partial t}+\nabla(v G)=0
$$

Here, we introduce the integral $\mathrm{L}$ over two points of $G$ in one dimension given as Equation (12).

$$
L_{x}=\int_{x_{i}}^{x} G(x, t) d x
$$

In the CIP-CSL2 scheme, the $L_{x}$ is also linked to advection through the following equation:

$$
\frac{\partial L_{x}}{\partial t}+v \frac{\partial L_{x}}{\partial x}=0
$$

Therefore, a volume conservation-type CIP equation in one dimension can be obtained and expressed as:

$$
\frac{\partial G}{\partial t}+v \frac{\partial G}{\partial x}=-G \frac{\partial v}{\partial x}
$$

Hence, Equation (10) can be solved by the following two equations under the phase of advection and non-advection conditions, respectively [20] by Equations (15) and (16), respectively as follows:

Phase of advection:

$$
\frac{\partial G}{\partial t}+v \frac{\partial G}{\partial x}=0
$$

Phase of non-advection:

$$
\frac{\partial G}{\partial t}=R+D-G \frac{\partial v}{\partial x}
$$

These equations are solved by determining $L$ as a cubic polynomial function.

The diffusion terms were discretised using the equations containing $G$ and $d$ given as follows:

$$
\begin{gathered}
\frac{\partial G}{\partial t}=\nabla d \nabla G+d \nabla^{2} G \\
\frac{G_{i}^{n+1}-G_{i}^{n}}{\Delta t}=\frac{1}{2} \frac{d_{1} G_{i+1}^{n}-d_{2} G_{i}^{n}+d_{3} G_{i-1}^{n}}{\Delta x^{2}} \\
d_{1}=d_{i+1}+d_{i} \\
d_{2}=d_{i+1}+2 d_{i}+d_{i-1} \\
d_{3}=d_{i}+d_{i-1}
\end{gathered}
$$

where $\Delta x$ is the grid size. We then developed a 3D simulator based on mathematical formulations, and the algorithm of the simulator is displayed in Figure 1.

\subsection{Discretisation accuracy}

To verify the accuracy of the CIP_CSL2, in this study, an advection-diffusion equation in a cuboid model (Figure 2) was examined. The system was set to $2 \times 1 \times 0.9(\mathrm{x} \times \mathrm{y} \times \mathrm{z})$ and the grid points, grid distance, and time increment were 405955 , 0.01667 , and 0.1 , respectively. The diffusion coefficient of the cylinder was selected randomly from $2.6 \times 10^{-8}$ to $3.4 \times 10^{-8}$. Additionally, we assumed that the $\mathrm{x}$-axis groundwater velocity $\left(v_{x}\right)$ was 0.001 and zero for the $y$ - and $z$-axes. In this verification, all parameters were dimensionless, so that no physical meaning is associated with the parameters, and the set values were appropriate. The relationship between the concentration of the cylinders and the analytical step is illustrated in Figure 3. The results from the CIP scheme and central difference method are also included for comparison with those for the CIP_CSL2 scheme. Evidently, the concentration of the cylinders from the CIP_CSL2 scheme is relatively stable even when the analytical step increases. The results obtained by the CIP scheme and central difference method are unstable. Hence, the suitability of the CIP_CSL2 scheme for this problem is demonstrated.

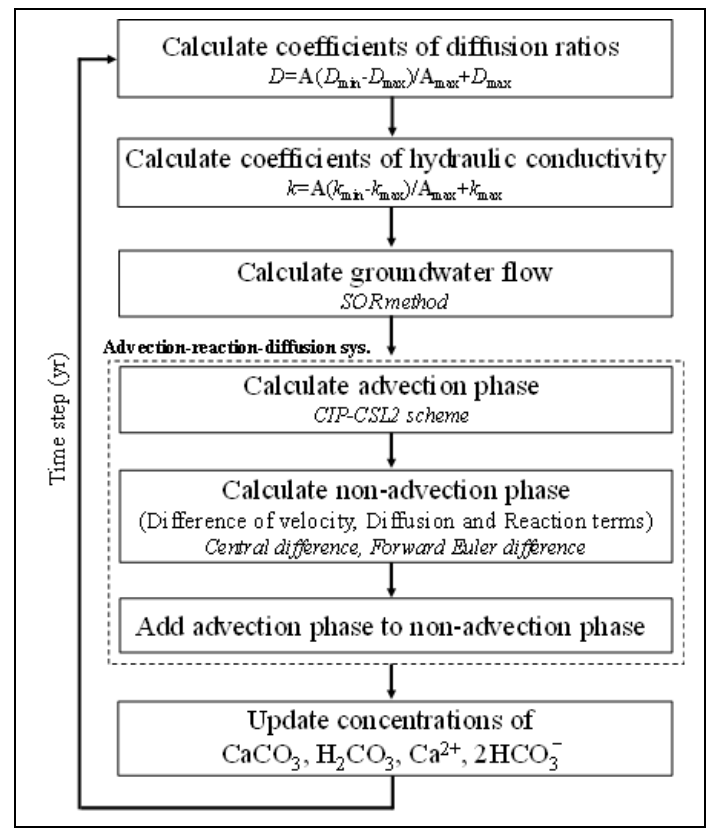

Figure 1. Calculation flowchart for the proposed simulator.

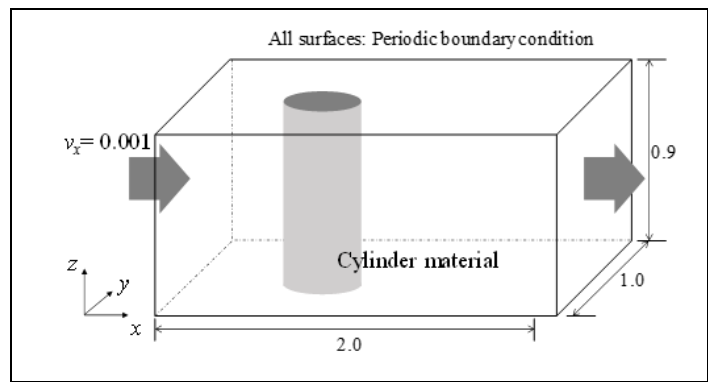

Figure 2. Scheme for the problem setup for discretisation accuracy.

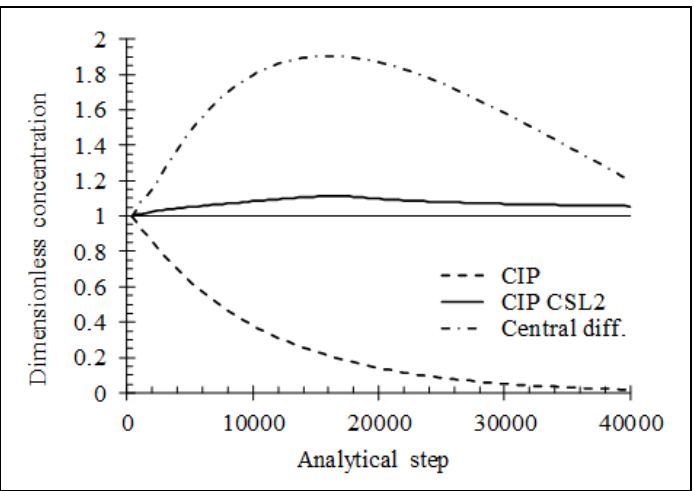

Figure 3. Stepwise variation in the concentration of dimensionless parameters. 


\section{Simulation and discussion}

\subsection{Model}

The 3D cuboid was selected as the test model in this study. To obtain the concentrations and reproduce the dissolution patterns of the calcium carbonate, we measured environmental parameters such as $\mathrm{pH}$, temperature, and $\mathrm{pCO}_{2}$. However, such environmental parameters were not introduced in Equations (2)-(5). In addition, determining the parameters that match the natural environment is quite difficult because the assumed chemical reactions constitute a simple system, as shown in Equation (1). Further, the temporal and spatial scales associated with the limestone dissolution model also differ from those in nature. Hence, we investigated mainly the morphological characteristics of the limestone dissolution in the subsequent numerical examples. Even so, each parameter must be consistent with real values, and therefore, the parameters in Equations (2)-(5) were selected based on existing experimental data [21]-[24].

Consequently, the system was set to $2 \times 1 \times 0.9 \mathrm{~m}^{3}(x \times y \times z)$, whereas the grid size and points were $0.0111 \mathrm{~m}$ and 1350622 , respectively. Regarding the grid system, we conducted preliminary simulations using three different models with 405955, 1350622, and 2453100 points before executing the main calculations. The differences between the solutions from these grid models were within $2 \%$. We, therefore, decided to employ the model involving 1350622 points, considering the computer resources. In addition, $\Delta t$ was set to $0.01 \mathrm{yr}$, with $D_{\text {Bmin }}=D_{\text {Cmin }}=D_{\text {Emin }}$ of $32.58 \times 10^{-5} \mathrm{~m}^{2} / \mathrm{yr}$, and $D_{\text {Bmax }}=D_{\text {Cmax }}=$ $D_{\text {Emax }}$ of $3.24 \times 10^{-3} \mathrm{~m}^{2} / \mathrm{yr}$ [22]. The reaction coefficients $k_{1}$ and $k_{2}$ in Equation (1) were set to 15.7 and $0.946 \mathrm{kmol} / \mathrm{m}^{2} \cdot \mathrm{yr}$, respectively [22],[23]. These values were also determined based on existing lab data [22],[23]. The assigned $k_{\max }$ and $k_{\min }$ were 1.0 and $0.8 \mathrm{~m} / \mathrm{yr}$, respectively.

In the cuboid system, the Neumann and periodic boundary conditions were set for the $\mathrm{x}-\mathrm{y}, \mathrm{x}-\mathrm{z}$ and $\mathrm{y}-\mathrm{z}$ surfaces, depicted in Figure 4. Additionally, 5.0 and $0.0 \mathrm{~m}$ were set as the corresponding potential heads for the left and right $y-z$ surfaces, respectively.

In the simulations, we initially located a hemisphere opening with radius of $0.2 \mathrm{~m}$ in the analytical region of each case. This reflects the expansion of a hemispherical cavity due to groundwater flow. The initial concentrations of the limestone and porous areas were $0.8-1.0$ and $0.0-0.3\left(\mathrm{kmol} / \mathrm{m}^{2} \cdot \mathrm{yr}\right)$, respectively. Concerning the structure of the limestone layers, four models with cavities and fractures were prepared, and these involved the following:

\section{(1) A normal model (Figure 4(a))}

A hemisphere cave was set in the cuboid region, and groundwater was injected into this hemisphere area.

(2) A spherical cavity model (Figure 4(b))

A hemispherical cavity and a spherical cavity were set in the cuboid region and groundwater was injected into the hemisphere.

(3) One-fracture model (Figure 4(c))

A hemispherical cavity and a plane fracture were set in the cuboid region and groundwater was injected into the hemisphere.

(4) Two-fracture model (Figure 4(d))

A hemispherical cavity and two plane fractures were set in the cuboid region and groundwater was injected into the hemisphere.

In this study, we investigated the expansion state of a hemispherical opening associated with groundwater flow in these four models and discuss the morphological changes.

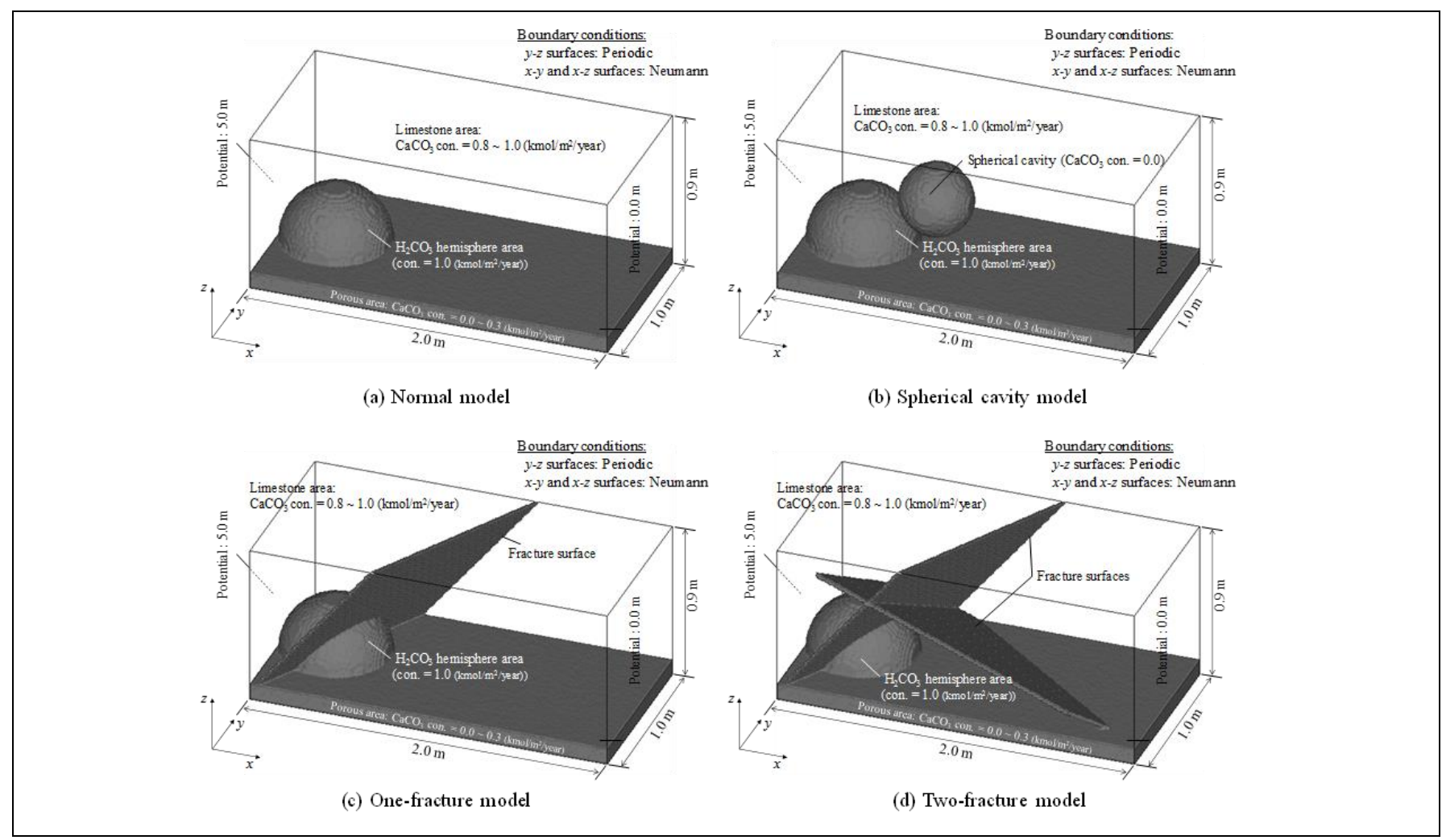

Figure 4. Simulation models involving four models of limestone dissolution. 


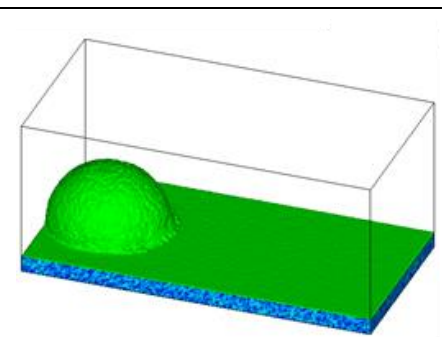

(a) $500 \mathrm{yrs}$

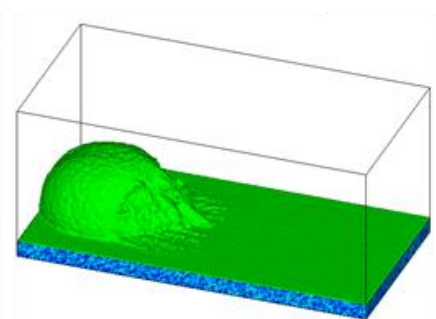

(b) $2000 \mathrm{yrs}$

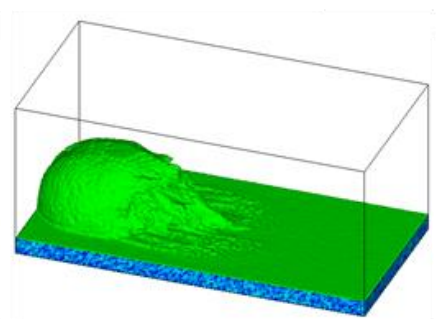

(c) $3000 \mathrm{yrs}$

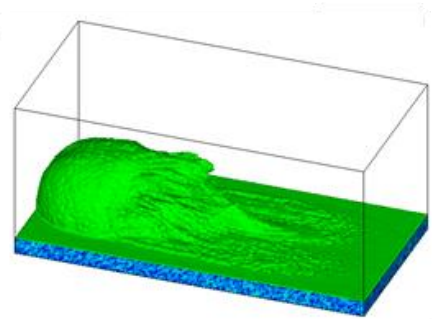

(d) $5000 \mathrm{yrs}$

Figure 5. Dissolution patterns of the calcium carbonate according to the normal model.

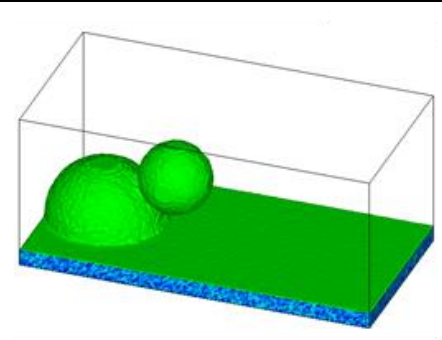

(a) $250 \mathrm{yrs}$

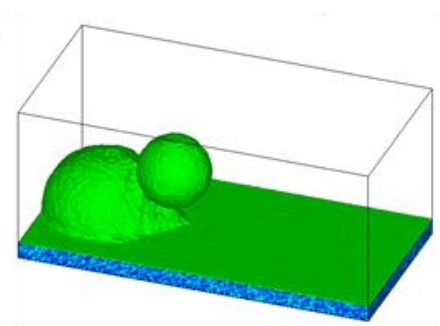

(b) $1000 \mathrm{yrs}$

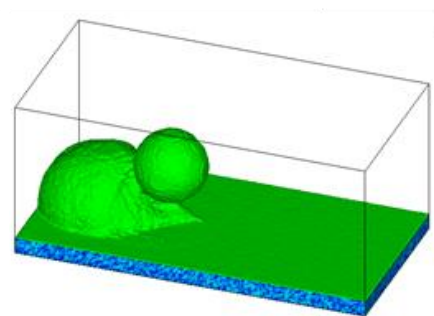

(c) $1500 \mathrm{yrs}$

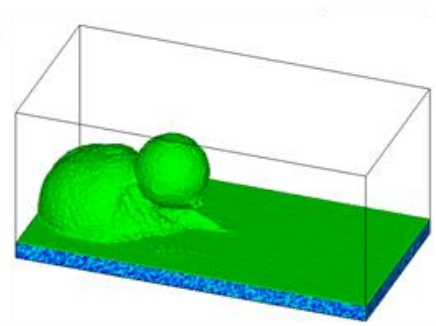

(d) $2500 \mathrm{yrs}$

Figure 6. Dissolution patterns of the calcium carbonate according to the spherical cavity model.

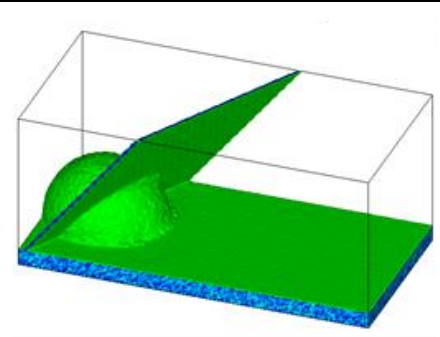

(a) $500 \mathrm{yrs}$

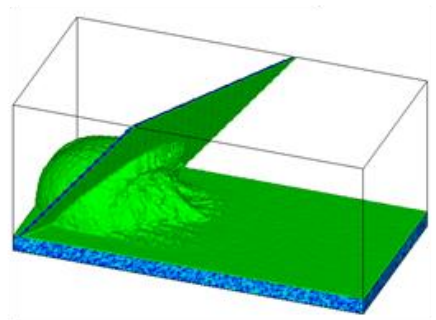

(b) $2000 \mathrm{yrs}$

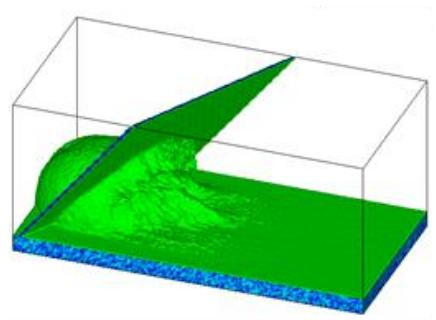

(c) $3000 \mathrm{yrs}$

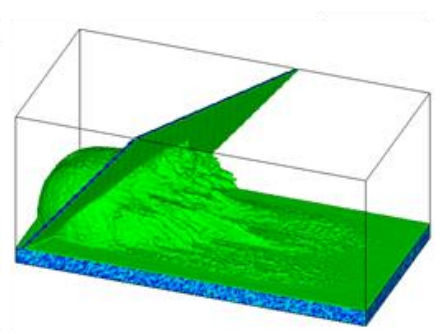

(d) $5000 \mathrm{yrs}$

Figure 7. Dissolution patterns of the calcium carbonate based on the one-fracture model.

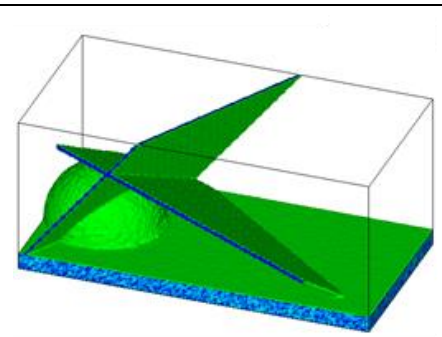

(a) $500 \mathrm{yrs}$

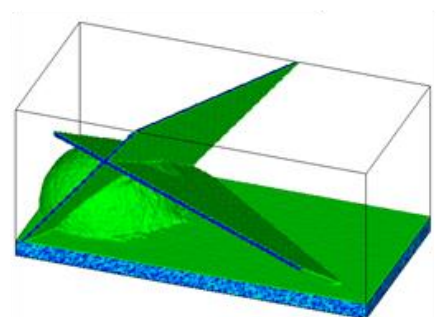

(b) $2000 \mathrm{yrs}$

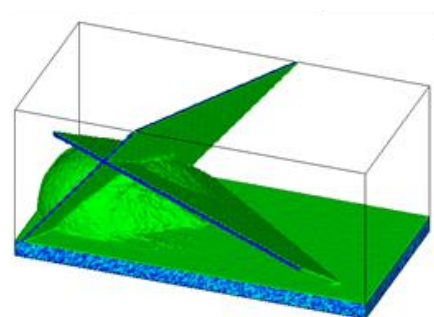

(c) $3000 \mathrm{yrs}$

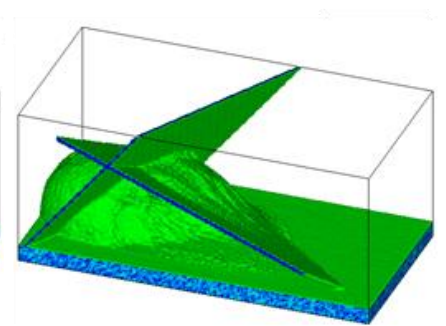

(d) $4000 \mathrm{yrs}$

Figure 8. Dissolution patterns of the calcium carbonate for the two-fracture model.

\subsection{Simulation results and discussion}

Figures 5-8 illustrate the spatial patterns of calcium carbonate dissolution over time for the normal, spherical, one-fracture, and two-fracture models, respectively. The green colours represent the calcium carbonate concentration isosurface. The corresponding groundwater flow patterns for the models are displayed in Figures 9-12. The isosurface of carbonic acid concentration is exhibited in blue.

Initially, the hemispherical opening expands in the groundwater flow direction from the left to the right in each case, and the calcium carbonate finally dissolves towards tunnel-like structures. The most complex spatial patterns and highest dissolution are associated with the models containing fractures. Conversely, the calculation for the spherical cavity model is unstable from approximately $2500 \mathrm{yr}$. According to Figures 9-12, these dissolution patterns are closely related to the water quantity. That is, the limestone dissolution progresses gradually from the surface in contact with water toward the groundwater flow direction. 


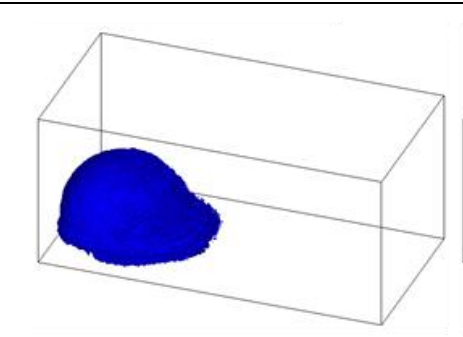

(a) $500 \mathrm{yrs}$

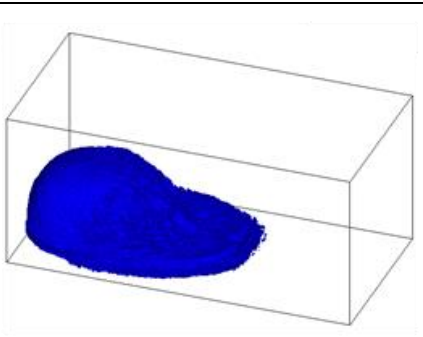

(b) $2000 \mathrm{yrs}$

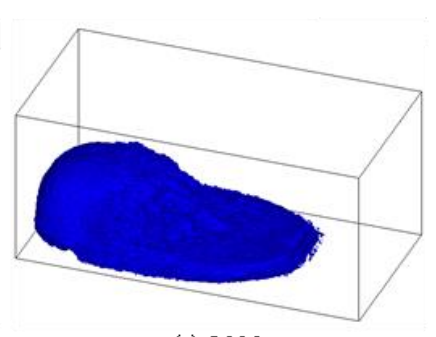

(c) $3000 \mathrm{yrs}$

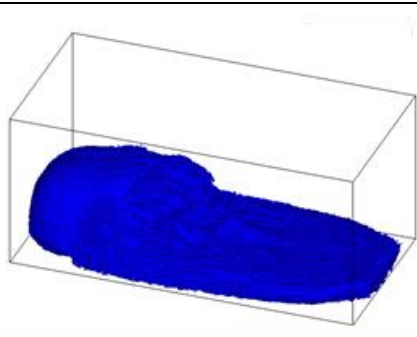

(d) $5000 \mathrm{yrs}$

Figure 9. Distribution patterns for the carbonic acid based on the normal model.

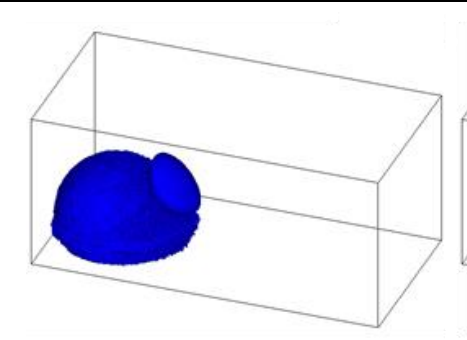

(a) $250 \mathrm{yrs}$

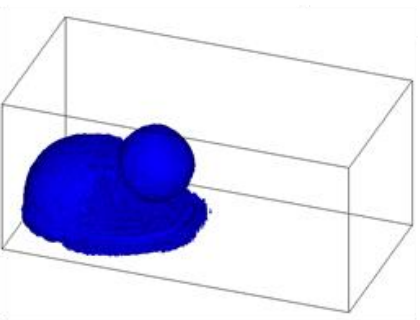

(b) $1000 \mathrm{yrs}$

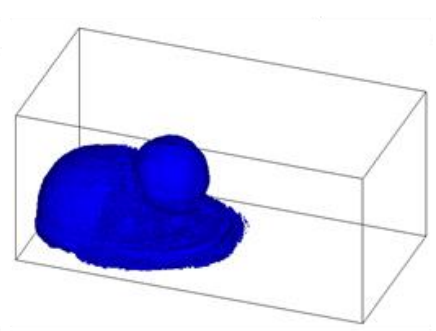

(c) $1500 \mathrm{yrs}$

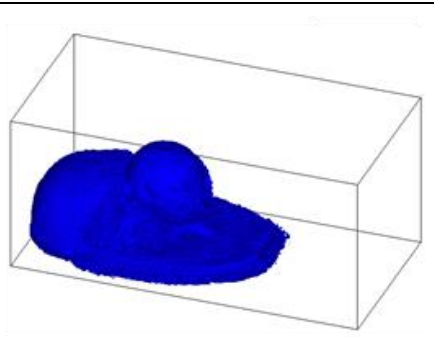

(d) $2500 \mathrm{yrs}$

Figure 10. Distribution patterns of the carbonic acid according to the spherical cavity model.

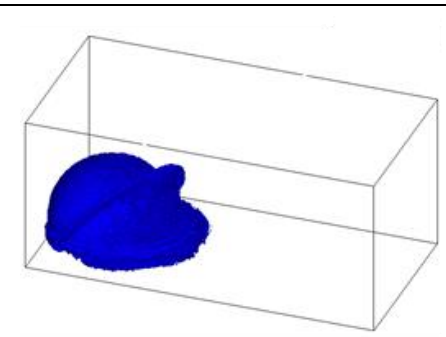

(a) $500 \mathrm{yrs}$

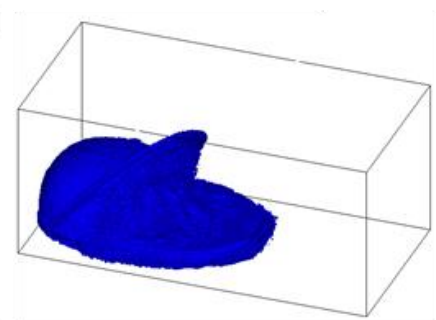

(b) $2000 \mathrm{yrs}$

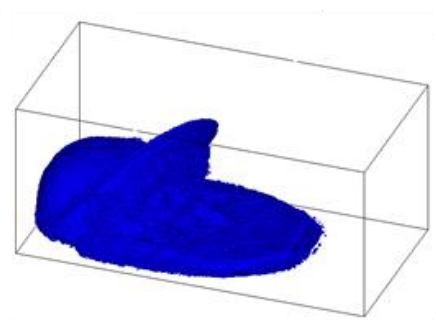

(c) $3000 \mathrm{yrs}$

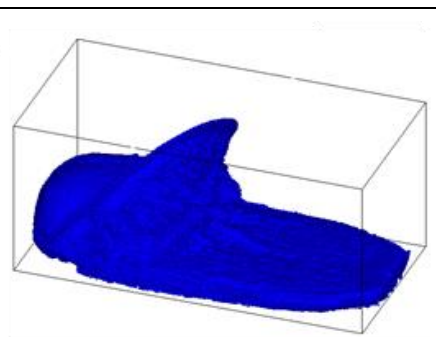

(d) $5000 \mathrm{yrs}$

Figure 11. Distribution patterns of the carbonic acid according to the one-fracture model.

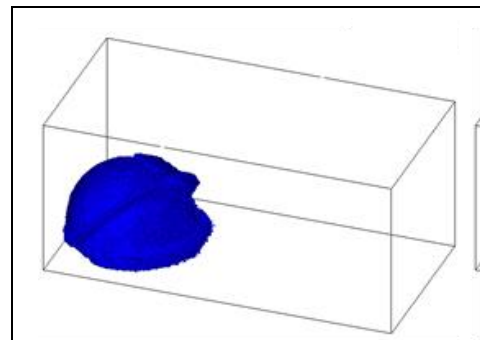

(a) $500 \mathrm{yrs}$

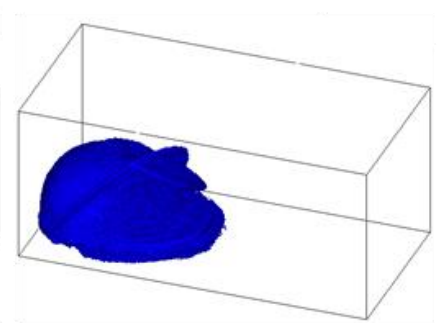

(b) $2000 \mathrm{yrs}$

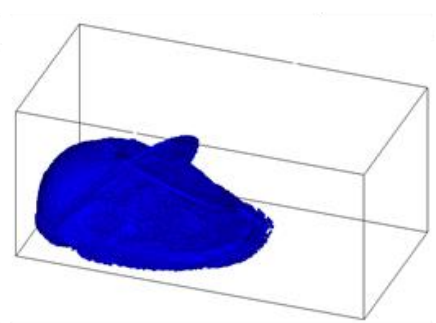

(c) $3000 \mathrm{yrs}$

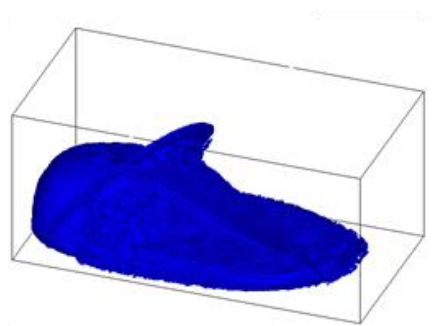

(d) $4000 \mathrm{yrs}$

Figure 12. Distribution patterns of the carbonic acid based on the two-fracture model.

In Figure 13, the normalised calcium carbonate (a) and normalised carbonic acid (b) concentrations are displayed on the vertical axis and the elapsed time is shown on the horizontal axis. Evidently, the dissolution rate is of the order spherical cavity model $<$ normal model $<$ one-fracture model $<$ twofracture model. Interestingly, the calcium carbonate profiles in all cases are nonlinear, corresponding to those of the carbonic acid concentrations despite constantly supplying groundwater to the hemispherical cavity. This indicates that the carbonic acid participates in the dissolution of the calcium carbonate.
In the simulations, the spherical cavity and two-fracture models failed at approximately 2500 and 4000 years, respectively. In the spherical cavity model, carbonic acid flowed in from approximately 500 years on and was stored. Conversely, for the two-fracture model, calcium carbonate dissolved along the surfaces of the fractures. Therefore, some complex behaviours of the calcium carbonate and carbonic acid observed in these models are simulated with insufficient accuracy by the proposed scheme. This is probably caused by poor accuracy of the finite difference method implemented in this study, and this should be improved in future. 


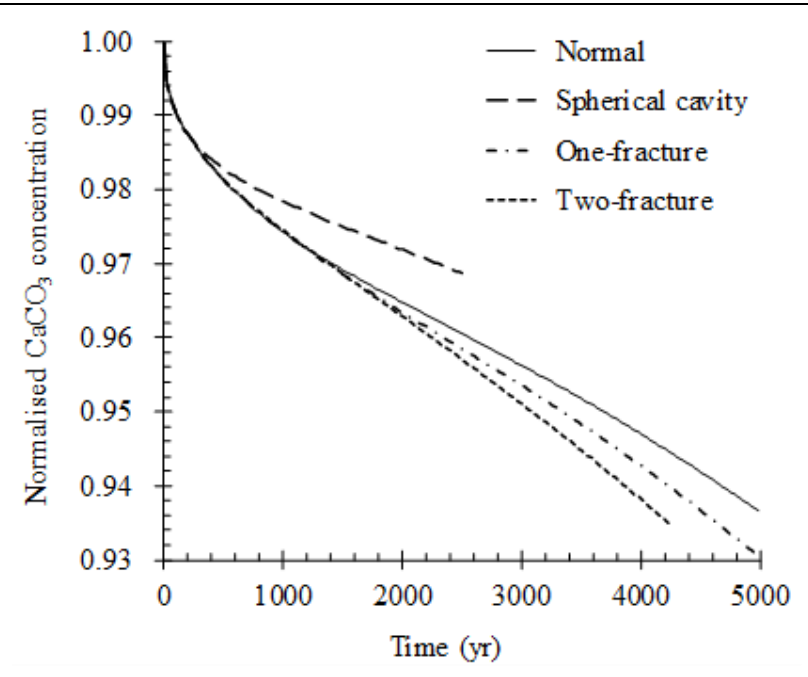

(a) Normali sed $\mathrm{CaCO}_{3}$ concentration

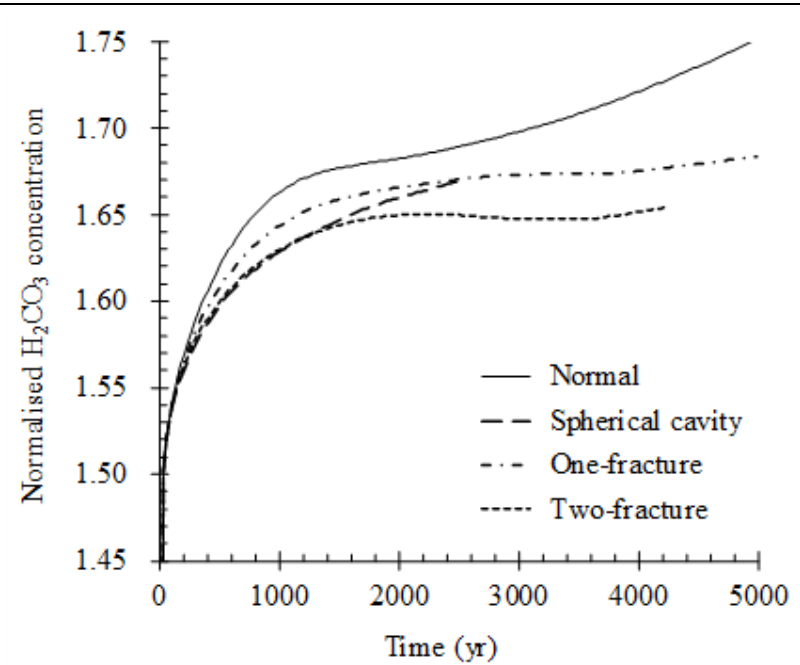

(b) Normalised $\mathrm{H}_{2} \mathrm{CO}_{3}$ concentration

Figure 13. Temporal variation of the normalised calcium carbonate and carbonic acid concentrations.

\section{Acknowledgment}

We acknowledge helpful discussions with Emeritus Prof. Ömer Aydan, Dr. Kosaburo Hirose, Mr. Ryogo Kawakami, and Prof. Halil Kumsar as well as comments and suggestions by anonymous reviewers. This work was supported by the University of the Ryukyus Strategic Research Grant (17SP01301).

\section{Conclusions}

In this study, a mathematical model and a numerical simulator for the 3D dissolution of calcium carbonate in limestone were proposed. The results suggest the following:

(1) The 3D spatial patterns of calcium carbonate dissolution from limestone were obtained from a system involving advection, reaction, and diffusion.

(2) The 3D complex dissolution patterns for different spatial conditions of limestone were achieved by the proposed simulator.

(3) The calcium carbonate dissolution was closely related to the groundwater flow, with the pores and cavities expanding in the groundwater flow direction.

(4) The calcium carbonate dissolution rate depended on its contact area with the groundwater.

Although the method proposed in this study is based on the approach of Matsubara and Yamada [11], this is not the only technique for analysing the geomorphological characteristics of karstic caves. Moreover, the occurrence of the caves and fractures were not included in the proposed model. However, the suggested approach greatly supports our understanding of karstic cave formation.

\section{References}

[1] Vacher HL, Mylroie JE. "Eogenetic karst from the perspective of an equivalent porous medium". Carbonates and Evaporites, 17(2), 182-196, 2002.
[2] Abbaszadeh M, Nasiri M, Riazi M. "Experimental investigation of the impact of rock dissolution on carbonate rock properties in the presence of carbonated water". Environmental Earth Sciences, 75(9), 791, 2016.

[3] Tiner RW. "Geographically isolated wetlands of the United States". Wetlands, 23(3), 494-516, 2003.

[4] Gutiérrez F, Parise M, De Waele J, Jourde H. "A review on natural and human-induced geohazards and impacts in karst". Earth-Science Reviews, 138, 61-88, 2014.

[5] Pokhrel RM, Kiyota T, Kuwano R, Chiaro G, Katagiri T, Arai I. "Preliminary field assessment of sinkhole damage in Pokhara, Nepal". ISSMGE International Journal of Geoengineering Case Histories, 3(2), 113-125, 2015.

[6] Tang CA, Kaiser PK. "Numerical simulation of cumulative damage and seismic energy release during brittle rock failure-Part I: Fundamentals". International Journal of Rock Mechanics and Mining Sciences, 35(2), 113-121, 1998.

[7] Hirose K, Matsubara H. "Mechanisms of mudcrack formation and growth in bentonite paste". Journal of Geotechnical and Geoenvironmental Engineering, 144(4), 04018017, 2018.

[8] Mamaghani IH, Aydan Ö, Kajikawa Y. "Analysis of masonry structures under static and dynamic loading by discrete finite element method". JSCE Structural Engineering and Earthquake Engineering, 16(2), 1-12, 1999.

[9] Kumsar H, Aydan Ö, Tano H, Çelik SB, Ulusay R. "An integrated geomechanical investigation, multi-parameter monitoring and analyses of Babadağ-Gündoğdu creep-like landslide". Rock Mechanics and Rock Engineering, 49(6), 2277-2299, 2016.

[10] Bouchelaghem F. "A numerical and analytical study on calcite dissolution and gypsum precipitation". Applied Mathematical Modelling, 34(2), 467-480, 2010.

[11] Matsubara H, Yamada T. "Mathematical and numerical modelling of limestone dissolution". Environmental Geotechnics, Ahead of Print, 2019, Doi:10.1680/jenge.18.00136. 
[12] Artamonova IV, Gorichev IG, Godunov EB. "Study of calcium and iron carbonate dissolution kinetics in order to resolve corrosion problems in carbonate solutions". Chemical and Petroleum Engineering, 50(9-10), 605-609, 2015.

[13] Aydan Ö. "Some Thoughts on the Risk of Natural Disasters in Ryukyu Archipelago". International Journal of Environmental Science and Development, 9(10), 282-289, 2018.

[14] Aydan Ö, Tokashiki N. "A comparative study on the applicability of analytical stability assessment methods with numerical methods for shallow natural underground openings". The $13^{\text {th }}$ International Conference of the International Association for Computer Methods and Advances in Geomechanics, Melbourne, Australia, 09-11 May 2011.

[15] Zumdahl SS, DeCoste DJ. Introductory Chemistry: A foundation. $8^{\text {th }}$ ed. Brooks Cole Pub. Co, 2018.

[16] Turing AM. "The chemical basis of morphogenesis". Philosophical Transactions of the royal society B, 237(641), 37-72, 1952.

[17] Budhu M. Soil Mechanics Fundamentals. $3^{\text {rd }}$ ed. New Jersey, USA, John Wiley \& Sons Inc., 2010.

[18] Yabe T, Tanaka R, Nakamura T, Xiao F. "An exactly conservative semi-Lagrangian scheme (CIP-CSL) in one dimension". Monthly Weather Review, 129(2), 332-344, 2001.
[19] Nakamura T, Tanaka R, Yabe T, Takizawa K. "Exactly conservative semi-Lagrangian scheme for multidimensional hyperbolic equations with directional splitting technique". Journal of Computational Physics, 174(1), 171-207, 2001.

[20] Smolarkiewicz PK, Pudykiewicz JA. "A class of semiLagrangian approximations for fluids". Journal of the Atmospheric Sciences, 49(22), 2082-2096, 1992.

[21] Alkattan M, Oelkers EH, Dandurand JL, Schott J. "An experimental study of calcite and limestone dissolution rates as a function of $\mathrm{pH}$ from- 1 to 3 and temperature from 25 to 80 C". Chemical geology, 151(1-4), 199-214, 1998.

[22] Boving TB, Grathwohl P. "Tracer diffusion coefficients in sedimentary rocks: correlation to porosity and hydraulic conductivity". Journal of Contaminant Hydrology, 53(1-2), 85-100, 2001.

[23] Chou LEI, Garrels RM, Wollast R. "Comparative study of the kinetics and mechanisms of dissolution of carbonate minerals". Chemical geology, 78(3-4), 269-282, 1989.

[24] Herman JS, Lorah MM. "Calcite precipitation rates in the field: measurement and prediction for a travertinedepositing stream". Geochimica et Cosmochimica Acta, 52(10), 2347-2355, 1988. 